\title{
Исследование работы диода Ганна в рамках новой многодолинной модели зоны проводимости
}

\author{
А.М. Можаров ${ }^{1}$, К.Ю. Шугуров ${ }^{1}$, Г.А. Сапунов ${ }^{1}$, В.В. Федоров ${ }^{1}$, И.С. Мухин ${ }^{1,2}$ \\ ${ }^{1}$ СПбАУ РАН, Академический университет, 194021, Санкт-Петербург, улица Хлопина, дом 8, корпус \\ 3, литер A \\ ${ }^{2}$ Университет ИТМО, 197101, Санкт-Петербург, Кронверкский пр., д. 49 \\ тел: +7 (921) 980-9929, эл.nочта: mozharov@spbau.ru
}

DOI 10.34077/RCSP2021-68

Электромагнитные волны терагерцового диапазона представляют большой интерес в современной науке и технике. В частности, сложные молекулы, такие как белки, ДНК и пр имеют резонансные пики в ТГц области спектра $[1,2]$. Наравне с рентгеновскими методами исследования, исследование положений резонансов можно делать выводы о строении молекул, а также о поведении молекул в сильных ТГц полях.

На текущий момент имеется широкий набор приборов для обработки ТГц излучения, но вопрос создания компактных маломощных источников до сих пор остается открытым. В качестве примера источников можно привести полупроводниковые квантово-каскадные лазеры, тонкие пленки низкотемпературного арсенида галлия, создающие ТГц излучение при облучении фемтосекундным лазерным импульсом, а так же диоды Ганна [3]. Диоды Ганна, в самом простом случае, не требуют создания сложных квантовых полупроводниковых структур для своей работы, однако электромагнитный диапазон их работы ограничен выбором материала и размерами активной области. Так, диоды Ганна, созданные на арсениде галлия, способны работать в ГГц области [4], в то время, как диоды на нитриде галлия $(\mathrm{GaN})$ способны уходить в ТГц область спектра. Рост нитрида галлия в виде нитевидных нанокристаллов (ННК) позволяет уменьшить количество дефектов в кристалле и существенно повысить качество материала, что сказывается граничной частоте работы диода Ганна.

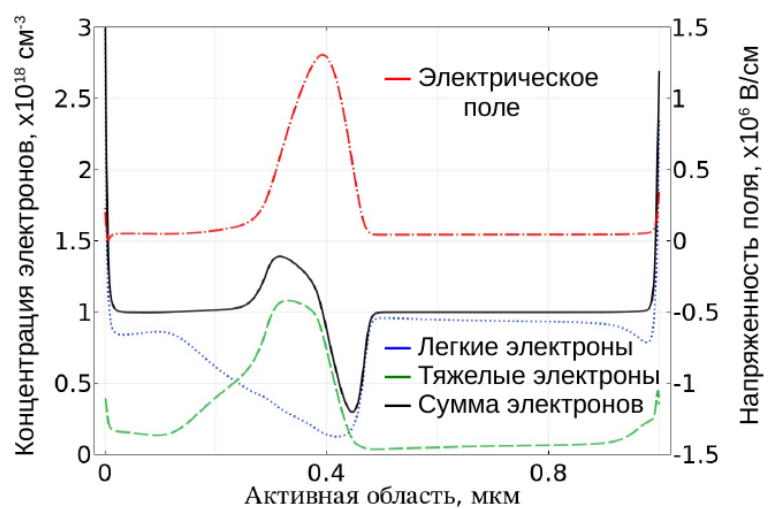

В данной работе будет представлена новая Рис. 1.Электронные домены в диоде Ганна аналитическая модель для описания работы диода

Ганна, учитывающая многодолинную структуру зоны проводимости полупроводника и кинетику перехода между долинами. Будут приведены результаты численного анализа работы диода Ганна на основе GaAs и $\mathrm{GaN}$ с использованием представленной модели.

Работа выполнена при финансовой поддержке стипендии Президента № СП-2169.2021.1. и поддержке Российского научного фонда (проект № 21-79-10346).

\section{Лumepamypa}

[1] Globus T. R. et al. THz-spectroscopy of biological molecules //Journal of biological physics. - 2003. T. 29. - №. 2. - C. 89-100.

[2] Laman N. et al. High-resolution waveguide THz spectroscopy of biological molecules //Biophysical journal. - 2008. - T. 94. - №. 3. - C. 1010-1020.

[3] Tonouchi M. Cutting-edge terahertz technology //Nature photonics. - 2007. - T. 1. - №. 2. - C. 97-105.

[4] Miles R., Harrison P., Lippens D. (ed.). Terahertz sources and systems. - Springer Science \& Business Media, 2001. - T. 27. 